\title{
Odpovědi na šíření koronaviru v islámském světě a boj o veřejnou racionalitu
}

\author{
Zora Hesová \\ Filosofický ústav Akademie věd ČR, CZ
}

HESOVÁ, Z: Responses to the Corona Pandemic in the Muslim World and Struggle for a Public Rationality

Philosophica Critica, vol. 6, 2020, no. 1, ISSN 1339-8970, pp. 150-160

If the Islamic world was stricken by the pandemic later than Asia and Europe, the responses are very similar to those of European and Asian states. A specificity of the Muslim world is the reaction of Islamic institutions. First, because of the danger of mass public gatherings, and secondly because of the legitimation role Islamic institutions play for many states in the Muslim world who dispose of a weaker infrastructural power or public or feeble public trust. If most religious institutions have responded in a supportive way and limited public rituals, the pandemics shifts power relations between state and religion and also alters the perceived superior kind of public rationality. The article offers a short overview on the state of the pandemics, the responses to it and discusses the political and discursive effects it may have.

Key words: Corona virus - Pandemics - Muslim Word - Islam Islamic autority - Secularisation - Public rationality

Islámský svět byl pandemií onemocnění COVID-19 zasažen s určitým zpožděním. Tvrdě dolehl na Írán a Turecko, jinde se zatím pandemie šírí pomaleji. $V$ islámském světě byly na začátku května nejpostiženějšími zeměmi Turecko (129 491 nemocných/3 520 úmrtí) a poté Írán (99 970/ 6340 ), řadí se tedy na 8. a 10. místě světového počtu nákaz. Dalšími, méně postiženými zeměmi, avšak s rostoucími počty nakažených, jsou Saúdská Arábie (30 251/200), Pákistán (22 049/514), Katar (17 142/12) a Spojené arabskéemiráty (15192/146).KméněnakaženýmpatříBangladéš $(10929$ / 183), Egypt (7 201/452), Malajsie (6 383/106), Maroko (5 219/181), Alžírsko (4 838/470), Kazachstán (4 205/29), Bahrajn (3 720/8), Omán 
(2 735/13), Irák (2 431/102), Ázerbájdžán (2 060/26), Bosna a Hercegovina (1 946/79), Tunisko (1 022/43), Libanon (741/25). Uvedená čísla je ale nutné brát s rezervou: jen málokterá země masivně testuje a zjištěné počty nakažených i zemřelých se často nezakládají na srovnatelných metodách. Přesto lze říci, že pandemie dnes prostoupila celým islámským světem, přičemž Írán, Malajsie a Turecko byly mezi prvními; rovněž lze konstatovat, že veškeré země přijímají ve více či menší míře podobná protipandemická opatření.

Odpovědi jsou ale všude obdobné a důsledky zatím neznáme. Muslimský svět není v tomto výjimkou. Zvláštní dopady bude mít ale pandemie na náboženství. Kromě toho, že zásadně omezila a omezí veřejný náboženský život během ramadánu a hadždže, bude mít i dopady na vzájemné vztahy mezi státem, islámem a veřejností. Protože si pandemie vynucuje autoritativní jednání založené na vědecky podložené racionalitě, je na místě se ptát, jak se tento masivní zásah do veřejnosti projeví v těch několika státech, jejichž oficiální ideologie je náboženská. Po krátkém přehledu týkajícím se odpovědí na pandemii bude možné je krátce zhodnotit a ptát se, jaké diskursivní efekty bude pandemie mít na vztah islámské politiky a náboženství a na převládající veřejnou racionalitu.

\section{Odpovědi na pandemii}

Odpovědi islámských zemí jsou různorodé v závislosti na síle, centralizaci a zdrojích státního aparátu. Výjimečným případem je moderní a autoritářská Malajsie, které se podařilo nákazu rychle a efektivně omezit v samém začátku krize díky kolektivní hygieně, dodržování odstupu, vysoké informovanosti a spolupráci občanů, masivnímu testování a karanténním opatřením.

Dalšími obět'mi nákazy jsou dva podobně lidnaté a relativně vyspělé a akceschopné státy. Írán patřil k silně zasaženým zemím, a to hned v druhé vlně, v samém začátku globální pandemie. I kvůli tomuto rychlému šíření přišla reakce státu s určitým zpožděním a nekoherentně, opatření se stupňovala a nedosáhla úrovně restrikcí ŕady jiných zemí. Přes modernizované zdravotnictví je íránská schopnost reakce silně omezená jednostranným embargem USA, které kriminalizuje obchod s Íránem. Země má tedy potíže vyvážet plyn a ropu - jejichž cena navíc silně klesla - a dovážet zdravotnický materiál. Írán se tak stal první silně nakaženou muslimskou zemí. Afghánští uprchlíci, často žijící v Î́ránu v ilegalitě, se masivně vracejí domů. Další silně zasažená země, Turecko, postupně přijala řadu striktních protiepidemických opatření jako uzavírání škol, a dokonce i uzavření třiceti jedna měst, zastavení veřejných akcí a nošení státem zajištěných 
neplacených roušek (Coronavirus: Turkey death toll passes 1,000). I tak se Turecko v první polovině dubna stalo jednou ze zemí s nejrychleji se širrící nákazou. Přes rostoucí počty nakažených považovaly Írán i Turecko odpověd' na nákazu za úspěšnou (Candar 2020). Turecko ovšem v dubnu předčilo Írán a přidalo další restrikce, ale snaží se plnit svou roli regionální mocnosti humanitárními gesty (více níže). Naopak Íránu se podle WHO podařilo zpomalit růst nákazy (Iran may stop mass gatherings in Ramadan to slow coronavirus sprej) a ten začíná uvolňovat určité protipandemické restrikce, ale zachovává nařízení sociálního odstupu.

Měsíc po oficiálním vypuknutí globální pandemie lze už říct, že sanitární krize je v islámském světě teprve v začátku a stane se zátěžovým testem pro vládní akceschopnost, ale i pro politické normy. Ropné státy jako Saúdská Arábie a Alžírsko budou muset čelit menším př́ímům z důvodu poklesu cen ropy a také oslabené legitimitě stávajících režimů. Írán, Irák, Alžírsko i Súdán se během loňského podzimu staly dějištěm masových protivládních protestů - ty krize sice zastavila, ale naopak uvalila další zkoušku na už tak kritizované vlády. Protipandemická opatření totiž přinášejí krátkodobou stabilitu, ale utlumení ekonomiky a omezení obživy početných chudých může vést k výraznému oslabení vlád - jež zpravidla nedisponují fondy na omezení sociálních dopadů. Proto jsou opatření zpravidla přijímána také až pod tlakem alarmujících čísel. Pákistánský premiér tak $\mathrm{v}$ polovině března nebyl ochoten přistoupit na prŕsný zákaz vycházení, jak to učinila sousední Indie, protože čtvrtina obyvatelstva „by zemřela hladem" (Janjua 2020).

Jiné země jsou naopak schopny vidět v krizi příležitost $\mathrm{k}$ vehementnímu prosazování nesouvisejících vládních politik. Turecko využilo krize k humanitární diplomacii. Přes pozastavené diplomatické vztahy mezi ním a Izraelem podpořilo zdravotnickým materiálem palestinskou samosprávu a Velkou Británii (Soylu 2020), jakož i Itálii, Španělsko a balkánské země. Maroko se zase chystá využít tvrdé restrikce, nabízené kompenzace a chytrou karanténu ke zvýšení informovanosti o vlastním obyvatelstvu a větší kontrole veřejných projevů. V Kosovu opozice s pomocí USA položila vládu a otevřela ústavní krizi v samém začátku epidemie (Isufi 2020).

Všude, i v méně zasažených zemích, jakými jsou Maroko, Súdán a Alžírsko (Coronavirus in the Islamic Word. The challenges of COVID-19), vlády postupně přistoupily k omezení pohybu na veřejnosti, letecké dopravy a masových akcí a k zavírání obchodů a škol. Ve všech zemích budou mít restriktivní opatření dopady na ekonomiku, zejména $v$ těch, které nemají finanční zásoby - jako např. v Jordánsku. $V$ těch nejméně rozvinutých či zasažených válkou lze očekávat devastující dopady na zdraví a obživu chudých vrstev obyvatelstva a také šíření nákazy mezi těmi, kdo závisejí 
na šedé ekonomice jako zdroji obživy. Země postižené válkou, nestabilitou nebo chudobou jako Jemen, Sýrie, Afghánistán a Súdán nedisponují dostatečnou lékařskou péčí, ventilátory, testy a ani finanční rezervou pro financování protipandemických opatření. Právě ve velkém počtu zemí ve válečném stavu lze přes dosavadní pomalý průběh očekávat nezvladatelné vypuknutí epidemie.

\section{Omezení náboženských rituálů}

Pandemie výrazně omezila a omezí náboženská shromáždění. Islámské instituce s určitým zdráháním přijaly restriktivní opatření. Jako první je byl nucen učinit Îrán: nákaza se zřejmě šiřila z Qomu, politického centra íránského šíitského islámu. Tam ji v začátku, ještě před vypuknutím otevřené krize, pravděpodobně urychlily hromadné náboženské rituály a koncentrace vysoce mobilních funkcionáruo islámské republiky. Írán se tak stal jednou ze zemí, kde nejenže se nakazili vedoucí politici, ale kde jich i řada zemřela (Iranian MP dies from coronavirus: Tasnim news agency). V Pákistánu a v Indii byly podobně jako v Jižní Koreji rané případy šíření nákazy spojené s globální misijní skupinou Tablihi Jamaat, která organizuje masová shromáždění a která v začátku odmítala přijmout omezení jejich shromáždění. Centra hnutí v Dilí, v Láhauru v Pákistánu a v Malajsii jsou podezřelá jako ohniska šíření (Miglani - Bukhari 2020). V Indii se o této skupině a o muslimech obecně šírí poplašné zprávy a dochází k svalování viny za pandemii na muslimy. Otevřená islamofobie prohloubila existující komunitní napětí mezi většinovými hinduisty a menšinovými muslimy.

Během března muslimové po celém světě omezili nebo zcela zastavili stěžejní islámský rituál a jeden z tzv. pilírư islámu, společnou páteční modlitbu. Pro svou hromadnost a rituální blízkost při řazení se do tzv. saffü, těsných modlitebních řad, je páteční rituál vysoce riskantní. První zemí, která toto zásadní opatření přijala, byl Írán. Jiné země se pokoušely sloučit páteční modlitby a tzv. sociální odstup, ale neúspěšně. Dnes už žádné páteční modlitby neprobíhají v nejméně dvanácti větších muslimských zemích, které byly nejvíce postiženy nákazou, a další země se k zavírání mešit postupně přidávají (Dwyer 2020).

Další zásadní omezení se bude týkat i dvou z pěti zbývajících rituálů. Na konci dubna začal postní měsíc ramadán, ve kterém je zvykem po večerech držet společné modlitby $v$ mešitě (taráwíh) a pořádat společná ukončení každodenního půstu v rodinném kruhu či ve společnosti jiných věŕících a sousedů - iftár. Ani taráwíh, ani iftár neprobíhají jako obvykle. Přestože např. Egypt určitá opatření během ramadánu změkčil, ramadán 
probíhá z větší části v izolaci. Dále pout’ do Mekky (hadždž), jejíž rituální sezóna začne v červenci, se nebude konat, respektive Saúdská Arábie nebude přijímat cizí poutníky a bude silně omezovat počet věřících na poutních místech. Už dnes jsou hranice Saúdské Arábie zavřené Íráncům, Kaaba v Mekce nedostupná, což platí i pro mešitu al-Aqsá v Jeruzalémě a ostatní centrální mešity islámského světa.

Větší islámské instituce státní politiky podpořily. Islám totiž určitý pojem karantény zná a nadřazuje lidský život rituálním povinnostem. Profesor Cafer Karadaš z univezity v Uludağu v Turecku připomíná hadíth, tedy tradovanou zpráva o př́kladném chování proroka Muhamada, ve kterém řekl, že pokud je v nějaké zemi mor, nikdo by tam neměl putovat, a naopak by neměl opouštět svou zemi, pokud ji mor napadne (Sofuoglu 2020).

\section{Náboženství pod kontrolou státu}

Náboženství není stěžejním rysem všech zemí muslimského světa a nebylo ani stěžejní silou v odpovědi na pandemii - jako důležitá společenská instituce však mělo jednu specifickou úlohu. Jak ukázala Sofia Fenerová (2020), v odpovědi na pandemii byla stěžejní rychlost a rozhodnost, infrastrukturní kapacita státu (Mann 1984) a také podpora obyvatelstva. Kromě váhajícího Íránu a Pákistánu dorazila nákaza do zbytku muslimského světa $v$ době, kdy již bylo jasné, že jde vážnou hrozbu. Většina států v muslimském světě přijala opatření omezující veřejná shromáždění, určité typy obchodu a hospodářského provozu např. v turismu a vyzvala k sociální distanci. Islám ale hrál i hlubší roli legitimizace politik těch států, jejichž kapacity jsou omezeny nefunkční infrastrukturou (např. zdravotního systému), nebo těch, jež nepožívají podporu veřejnosti např́íklad kvůli své autoritářské struktuře.

Celá řada muslimských států skutečně „mobilizovala“ náboženské instituce, a to nejen v úsilí dodržovat tzv. sociální distanci, a tedy omezit náboženská shromáždění, zavřít mešity pro páteční modlitby a prožívat ramadán v izolaci. Státy potřebují podporu náboženských autorit zejména tam, kde samy nedisponují potřebnou legitimitou pro přijímání drastických opatření, např. zákazu vycházení, který byl v rưzných obdobách uvalen v Maroku, Saúdské Arábii, Turecku i Egyptě.

Nákaza ukázala různé formy náboženské organizace neboli tzv. governance of islam. $V$ centralizovaných zemích se silným státem a státním dozorem nad náboženskými organizacemi, jako je Írán, Turecko, Saúdská Arábie a Egypt, bylo toto opatření možné rychle přijmout a vynutit. V Turecku zavření mešit oznámil ministr náboženských záležitostí Ali 
Erbaš a jeho úřad nechal doplnit tradiční výzvu k modlitbě (tzv. ezán) doporučením modlit se doma (Ibrahim 2020). Jinde se modlitba z prázdných mešit přenáší mikrofony či přes internet; imámové vystupují s rouškami.

V zemích, kde vládne spíše neoficiální autorita jednotlivých duchovních, dostali věřící doporučení: např. vlivný ajatolláh Sístání v Iráku vyzval věřící $\mathrm{k}$ protiepidemickým opatřením a $\mathrm{k}$ vyvarování se náboženských shromáždění. Podobě i v Indonésii se vyslovily organizace islámských duchovních na podporu sociálního odstupu (Muslims in Indonesia divided over Friday prayers amid coronavirus fears) a Jakarta zavřela mešity; v některých místech největšího muslimského státu, rozprostírajícího se na tisíci ostrovů, ale shromáždění pokračovala. V Pákistánu vyjednávala vláda se zástupci náboženských skupin, ale ne všechny dodržují její doporučení (Janjua 2020). Sama vláda ale v polovině března zastavila pozdě čtvrtmiliónové mezinárodní setkání skupiny Taglihi Jamaat, a umožnila tak šiřrení právě začínající nákazy.

Ve skutečnosti se ale protipandemická opatření zapsala do dlouhodobého procesu, ve kterém státy ve většině zemí postupně posilují svou kontrolu nad tradičně polycentrickou a nezávislou náboženskou sférou. Zejména od propuknutí tzv. arabského jara v roce 2011 státy jako Egypt, Maroko a Turecko posílily kontrolu mešit, nadací, autorit a pátečních modliteb $\mathrm{v}$ rámci tzv. prevence násilného extremismu a potlačování islamistické opozice. Tato „sekuritizace islámu“ ale často vede linii mezi institucemi ochotnými se státem spolupracovat a skupinami, které byly méně ochotné. Státní kontrola náboženství politizuje a nezřídka posiluje právě nestandardní chování jako protišíitské sektářství, mesianismus a konspirační teorie. Hlasy o tzv. šíitském viru byly slyšet v Egyptě a v Saúdské Arábii. V Turecku a v Íránu byl virus spojován s protiamerickou a pročínskou propagandou (Bakeer 2020). Íránský duchovní Alireza Panahian zase prohlašoval, že COVID-19 je znakem příchodu Mahdího a konce světa (Jones 2020). Nestátní aktéři jako salafistické opoziční skupiny a džihádisté pandemii zase využily pro vlastní agendu: al-Káida označila nákazu za boží trest za mravní zkaženost, ale i ona přijala protipandemická opatření (Al-Qaeda Central: COVID-19 is divine punishment for sins of mankind). Tzv. Islámský stát přivítal pandemii jako trest Západu a zvýšil svou aktivitu v Sýrii a v Iráku (al-Khateb 2020). Stejně jako v jiných zemích se pandemie stala předmětem konspiračních teorií.

\section{Boj o racionalitu}

Náboženské instituce naopak státní politiky podpořily a výše zmíněné výstřelky neměly větší odezvu. Naopak řada komentátorů poukázala na to, 
že zvládání pandemie si vyžaduje určitou praktickou, vědecky podloženou racionalitu. Ta ale stojí v prímém protikladu s tradicionalistickým výkladem náboženství, který byl v posledním desetiletí na vzestupu mezi fundamentalistickými skupinami. Podle tureckého publicisty Mustafy Akyola představuje prosazení státní logiky krok směrem k prohloubení sekularizace (Akyol 2020). Pandemie totiž ukázala zcela jednoznačně, že logika osobní a kolektivní bezpečnosti a národního zájmu převládá nad logikou náboženských povinností a náboženského ritualismu. Fundamentalisté měli tendenci nákazu z náboženských důvodů zlehčovat, ale i oni museli nakonec přijmout racionální, sekulární řešení. Př́́kladem je kromě výše zmíněného masového hnutí Tablighi Jamaat i ajatolláh Tabrizian. Tento duchovní působící v íránském centru politického islámu v Qomu již dříve tvrdil, že umí léčit rakovinu skrze pobožnost. Jeho bizarní návrhy pro léčení nemoci COVID-19 mu ale v Íránu vynesly jen posměch mladých Íránců (Faghihi 2020). Rychlá kolize s racionalitou nebyla, jak připomíná Mustafa Akyol, jen údělem muslimských fundamentalistů. V USA ztratily nábožensky podložené odmítavé postoje kazatele Jerryho Falwella jr. v jeho Liberty University, u newyorských hasidů kredibilitu, když se ukázalo, že vedly k šíření nákazy.

Kromě diskreditace fundamentalismu může mít prosazování určitého typu moderní racionality zásadní politické dopady právě ve státech nábožensky inspirovaných a ř́zených. V momentě krize totiž stát nepokrytě demonstruje svou reálnou moc nad náboženstvím, a to i tehdy, když se náboženstvím běžně zaštituju jako největší hodnotou. $V$ muslimském světě je hned několik velkých států tohoto druhu: islámské republiky Írán a Pákistán, království Saúdská Arabie, a v poslední době bychom mohli přidat i islamisty řízené Turecko.

V Íránu byla plná suverenita státu, který vládl ve jménu náboženství, zřejmá ihned po revoluci: ajatolláh Chomejní např. zakázal tradiční šíitské procesí rituálního truchlení za imámem Husajnem během měsíce muharramu - jelikož velká shromáždění představovala pro vznikající režim nebezpečí. Tato procesí byla později obnovena. Uzavření mešit, a zejména hrobek imámů, které Íránci považují za svatá místa a také za místa uzdravení, jsou ale bezprecedentní. Hrobku imáma Rezy v Mašhadu např. navštíví ročně dvacet miliónů šíitů, tedy asi čtvrtina země. Jejich uzavření také nebylo okamžité, trvalo asi měsíc, než se vláda k tomuto kroku rozhodla. Následovaly protesty ze strany místních a kleriků. Podle Azadeh Zamiriradové z německé Nadace věda a politika (Zamirirad 2020) má demonstrace státní suverenity nad náboženstvím za důsledek „demystifikaci“ dlouhověkých šíitských přesvědčení např. o léčící moci hrobek. Íránský stát přitom vždy racionálně, moderně nejednal. Prezident Ahmadínežád 
byl přívržencem šíitské apokalyptické tendence, jež očekávala brzký konce světa, a legitimoval tímto postojem politiku. Írán také podporoval alternativní islámskou medicínu. Ta dlouhodobě přitahuje pozornost: jak píše Zamiriradová, léčení recitací Koránu nebo uzdravení poutí k hrobkám svatých ted” ale muselo „ustoupit realitě“. Stát byl nucen oddělit medicínu od pověry. Protože ale íránská státní ideologie přinejmenším mlčky určité magické praktiky podporovala, rozhodný postoj státu ted' může vést $\mathrm{k}$ „teologické krizi“.

Pro přívržence sekulárního státu naopak krize skýtá naději, že urychlí „postupnou kulturní transformaci Íránu“. Přrírodní katastrofy přispěly „k odkouzlení náboženství", jak píše Zamiridad, v dějinách Evropy. Právě oddělení politické a náboženské sféry, ke kterému skrze pandemii dochází, ale popírá ideologický základ Islámské republiky. Pandemie tedy přinese nutnost intelektuálně zpracovat a potřebu veřejně diskutovat vztah náboženství a politiky, jak to ostatně činí i tzv. noví náboženští myslitelé v čele s Abdulkarímem Sorúšem od poloviny devadesátých let. Podobou úvahu vede turecký politolog Gökhan Bacik, působící na univerzitě v Olomouci (Bacik 2020). Konstatuje, že současná krize oslabí tradicionalistické interpretace islámu. Dosud to byli tradicionalisté, kteří tvrdili, že náboženství skýtá odpovědi na všechny problémy lidstva. Tváří v tvář sanitární krizi ale veřejný prostor ovládli vědci a „poprvé stali hlavní referencí ve společnosti“ a předčili i náboženské osobnosti, a vydobyli tak autoritu vědě. Podle Bacika dochází ke generační změně: pandemie společensky podpoří distancovaný postoj mladé generace „moderních Turkü“ k politizovaným a tradicionalistickým výkladům islámu.

\section{Závěr: výhled}

Ovšem chápat pandemii jako př́ležitosti k prosazování moderního typu racionality předpokládá, že ji zmíněné státy zvládnou. Přesto, že některé země začátkem května již zmírňovaly opatření, plný dopad pandemie bude zřejmý až na podzim. $V$ té době bude možné vyčíslit ztráty z propadlé turistické sezóny, ze které žije Tunisko, Turecko, Egypt atd. Bude také jasné, o kolik přišly státní kasy ropných států, kolik remitencí neposlali př́buzní z Evropy a Ameriky zpět do zemí, kde na nich závisejí celé rodiny, a zda obchodní omezení nevedla k nedostatečnému zásobování potravinami, co je pro potravinově nesoběstačné země Severní Afriky a Blízkého Východu. Je možné si představit velmi rozdílné dopady. I pokud se podaří zpomalit či zastavit pandemii, neschopnost při zvládání jejích důsledků může oslabit legitimitu řady autoritářských režimů - např. rodiny Saúdů. Na druhou stranu ale pandemie nutně oslabí i reformistická 
hnutí. Od roku 2018 probíhá druhá vlna tzv. arabského jara. Nenásilné, prodemokratické mobilizace např. v Alžírsku, Iráku a Súdánu od začátku krize neprobíhají a hospodářský propad může vysílit hnutí, která již trvají dlouho a bez výsledku.

Bitva o racionalitu probíhá i na diskursivní úrovni. I v muslimském světě se skloňují historické př́iklady přírodních katastrof a jejich dopadů. Zmíněný Mustafa Akyol připomíná dopady zemětřesení v Lisabonu a očekává obdobnou sekularizaci myšlení v islámském světě. Naopak Ali al-Qaradaghi, předseda konzervativní International Union of Muslim Scholars vidí $\mathrm{v}$ pandemii př́ležitost a odkazuje $\mathrm{k}$ tzv. justiniánskému moru, který v 6. století oslabil Byzanc a otevřel cestu šíření islámu. Jiní vidí v pandemii př́ležitost se kriticky zamyslet nad světem, ve kterém žijeme. Podle Preporodu, novin islámské obce v Bosně, není dnešní situace jedinečná ve 14. století byly v Egyptě podle historika al-Maqrízího zavřeny všechny mešity do jedné. Bosenský muftí proto nabádá věřící $\mathrm{k}$ tomu, aby se vyvarovali „pseudoučitelů“, kteří vyvolávají strach, postavili se krizi čelem, využili tradičního usebrání během ramadánu a zamysleli se nad zítřejšími výzvami (Mustafić 2020). Daleko největší z nich je krize ekologická. Husein ef. Kavazović explicitně přivítal civilizační zpomalení během pandemie: „At’ si země od nás odpočine.“

\section{Literatura}

AKYOL, M. (2020): Thou shalt practice social distancing. 8. 4.2020. Web. 30. 4. 2020. <https://foreignpolicy.com/2020/04/08/thou-shalt-practice-socialdistancing/>.

AL-KHATEB, K. (2020): Islamic State spreading terror once again in Syrian desert. 12. 4. 2020. Web. 30. 4. 2020. <https://www.al-monitor.com/pulse/ originals/2020/04/syria-east-deser-islamic-state-attacks-regime-iran.html .

Al-Qaeda Central: COVID-19 is divine punishment for sins of mankind; Muslims must repent, west must embrace Islam. 1. 4. 2020. Web. 30. 4. 2020. <https:// www.memri.org/reports/al-qaeda-central-covid-19-divine-punishment-sinsmankind-muslims-must-repent-west-must>.

BACIK, G. (2020): Coronavirus pandemic strengthens secular outlook in Islamic Word. 30. 3. 2020. Web. 30. 4. 2020. <https://ahvalnews.com/turkeycoronavirus/coronavirus-pandemic-strengthens-secular-outlook-islamicworld>.

BAKEER, A. H. (2020): Coronavirus: Why conspiracy theories have taken root in Turkey. 3. 4. 2020. Web. 30. 4. 2020. <https://www.middleeasteye.net/ opinion/coronavirus-turkey-why-conspiracy-theories-have-taken-root>.

CANDAR, C. (2020): Turkey and COVID-19: Is another Italy in the making? 26. 3. 2020. Web. 30. 4. 2020. <https://www.al-monitor.com/pulse/originals/ 2020/03/turkey-might-be-another-italy-in-the-making-coronavirus.html>. 
Coronavirus in the Islamic Word. The challenges of COVID-19. 13. 3. 2020. Web. 30.4.2020.<https://en.qantara.de/content/coronavirus-in-the-islamic-worldthe-challenges-of-covid-19>.

Coronavirus: Turkey death toll passes 1,000.10.4.2020. Web. 30.4.2020.<https:// www.middleeasteye.net/news/coronavirus-turkey-death-toll-passes-1000>.

DWYER, C. (2020): Coronavirus fears derail friday prayers for muslims across the world. 19. 3. 2020. Web. 30. 4. 2020. <https://www.npr.org/sections/ coronavirus-live-updates/2020/03/19/818337269/coronavirus-fearsderail-friday-prayers-for-muslims-across-the-world?t=1586806001645>.

FAGHIHI, R. (2020): A cleric's cure for coronavirus becomes butt of jokes in Iran. 10. 4. 2020. Web. 30. 4. 2020. <https://www.al-monitor.com/pulse/originals/ 2020/03/bizarre-cures-for-coronavirus-in-iran.html>.

FENER, S. (2020): State, regime, government, and society in COVID-19 response: establishing baseline expectations. Web. 30. 4. 2020.<https://duckofminerva. com/2020/03/state-regime-government-and-society-in-covid-19-responseestablishing-baseline-expectations.html>.

IBRAHIM, A. (2020): Praying in time of COVID-19: How world's largest mosques adapter. 2. 4. 2020. Web. 30. 4. 2020. <https://www.aljazeera.com/ news /2020/04/praying-time-covid-19-world-largest-mosques-adapted200406112601868.html>.

Iran may stop mass gatherings in Ramadan to slow coronavirus sprej. 9. 4. 2020. Web. 30. 4. 2020. <https://www.middleeasteye.net/news/coronavirus-iranmass-gatherings-ramadan>.

Iranian MP dies from coronavirus: Tasnim news agency. 7. 3. 2020. Web. 30. 4.2020. $<$ https://www.straitstimes.com/world/middle-east/iranian-mp-dies-fromcoronavirus-tasnim-news-agency>.

ISUFI, P. (2020): On top of COVID-19, Kosovo faces constitutional crisis. 2. 4. 2020. Web. 30. 4. 2020. <https://balkaninsight.com/2020/04/02/on-top-of-covid19-kosovo-faces-constitutional-crisis/>.

JANJUA, H. (2020): Coronavirus and Islam. Pakistani clerics refuse to shut down mosques. 9. 4. 2020. Web. 30. 4. 2020. <https://en.qantara.de/content/ coronavirus-and-islam-pakistani-clerics-refuse-to-shut-down-mosques>.

JONES, R. (2020): Corona: Muslims also say Messiah is coming. 22. 4. 2020. Web. 30. 4. 2020. <https://www.israeltoday.co.il/read/corona-muslims-also-saymessiah-is-coming/

MANN, M. (1984): The autonomous power of the state: its origins, mechanisms and results. In: European Journal of Sociology, 25 (2), 185 - 213.

MIGLANI, S. - Bukhari, M. (2020): India and Pakistan crack down on Muslim group emerging as COVID-19 cluster. 1. 4. 2020. Web. 30. 4. 2020. <https://www. thejakartapost.com/news/2020/04/01/india-and-pakistan-crack-down-onmuslim-group-emerging-as-covid-19-cluster.html>.

Muslims in Indonesia divided over Friday prayers amid coronavirus fears. 20. 3. 2020. Web. 30. 4. 2020. <https://www.reuters.com/article/us-healthcoronavirus-mosques/muslims-in-indonesia-divided-over-fridayprayers-amid-coronavirus-fears-idUSKBN2170ZF>. 
MUSTAFIĆ, S. (2020): Džamije su se zatvarale i prije. 18. 3. 2020. Web. 30. 4. 2020. $<$ https://www.preporod.info/bs/article/15490/dzamije-su-se-zatvaralei-prijes.

SOFUOGLU, M. (2020): What Islam tells us about responding to deadly pandemics. 15. 4. 2020. Web. 30. 4. 2020. <https://www.trtworld.com/magazine/whatislam-tells-us-about-responding-to-deadly-pandemics-35441>.

SOROUSH, A. (2002): Reason, Freedom, and Democracy in Islam. Essential Writings of Abdolkarim Soroush. Oxford: Oxford University Press.

SOYLU, R. (2020): Coronavirus: Turkey to deliver medical supplies to Israel. 10. 4. 2020. Web. 30. 4. 2020. <https://www.middleeasteye.net/news/ coronavirus-turkey-sells-israel-medical-supplies>.

ZAMIRIRAD, A. (2020): Three implications of the corona crisis in Iran. Point of View, Stiftung Wissenschaft und Politik. Web. 30. 4. 2020. <https://www.swp-berlin. org/en/publication/three-implications-of-the-corona-crisis-in-iran/>.

\section{Zora Hesová, PhD.}

Centrum globálních studií

Filosofický ústav Akademie věd ČR

Jilská 1,11000 Praha 1

Česká republika

hesova@flu.cas.cz 